\title{
Kaplamalı ve Kaplamasız Karbür Matkap ile Ferritik Paslanmaz Çeliğin Delinebilirlik Analizi
}

\author{
Tolga MERAL ${ }^{\mathrm{a}}$, Mustafa GÜNAY ${ }^{\mathrm{b}, *}$ \\ ${ }^{a}$ Uludağ Üniversitesi Teknik Bilimler Meslek Yüksekokulu, Makine ve Metal Teknolojisi Bölümü, Bursa 16059, TÜRKIYYE \\ ${ }^{b, *}$ Karabük Üniversitesi Mühendislik Fakültesi, Makine Mühendisliği Bölümü, Karabük 78050, TÜRKIYE \\ MAKALE \\ BÍLGISİ \\ Alınma: 28.05.2019 \\ Kabul: 08.08.2019

Anahtar Kelimeler:
AISI 430
İlerleme kuvveti
Yüzey pürüzlülüğ̈u
Çaptan sapma
'Sorumlu Yazar:
e-posta:
mgunay@ karabuk.edu.tr \\ ÖZET

\begin{abstract}
İşlenebilirliği zor malzemelerin matkap ile delinmesi söz konusu olduğunda, özellikle ilerleme miktarı, kesme hızı ve takım geometrisine bağlı olarak delik kalitesi değişmektedir. Bu nedenle, yeni matkap kalitesi ve geometrileri geliştirilmekle birlikte, ilerleme miktarı ve kesme hızının kesme kuvveti, yüzey kalitesi, ölçü tamlığı gibi delinebilirlik kriterlerine etkileri üzerine yapılan çalışmalar güncelliğini korumaktadır. Bu çalışmada, ferritik paslanmaz çeliğin kaplamalı ve kaplamasız karbür matkap ile delinebilirliği araştırılmıştır. Paslanmaz çeliğin delinmesinde oluşan ilerleme kuvveti, yüzey pürüzlülüğü ve çaptan sapma üzerinde ilerleme miktarı ve kesme hızının etkileri deneysel ve istatistiksel olarak analiz edilmiştir. Deneyler, karbür matkap ucu ile üç farklı kesme hızı $(15,30,45 \mathrm{~m} / \mathrm{dak})$ ve ilerleme miktarında $(0.12,0.16,0.2 \mathrm{~mm} / \mathrm{dev})$ yapılmıştır. Delme parametrelerinin işleme çıktıları üzerindeki etki seviyelerini belirlemek amacıyla varyans analizi uygulanmıştır. Deneysel sonuçlara göre, ilerleme miktarı arttıkça ilerleme kuvveti ve yüzey pürüzlülüğü artarken, çaptan sapmanın azaldığı belirlenmiştir. Deneysel ve istatistiksel sonuçlara göre, yüzey pürüzlülüğü ve çaptan sapma için kaplamalı karbür matkap kaplamasıza göre sırasıyla ortalama \%5.8 ve \%8.3, ilerleme kuvveti için kaplamasız matkabın kaplamalıya göre ortalama $\% 10$ daha iyi performans gösterdiği belirlenmiştir.
\end{abstract}

\section{Drillability Analysis of Ferritic Stainless Steel with Coated and Uncoated Carbide Drill}

\section{ARTICLE \\ INFO}

Received: 28.05.2019

Accepted: 08.08.2019

\section{Keywords:}

AISI 430

Thrust force

Surface roughness

Deviation of diameter

\section{"Corresponding}

$\underline{\text { Authors }}$

mgunay@karabuk.edu.tr

\begin{abstract}
The hole quality varies particularly depending on the feed rate, cutting speed and tool geometry in the case of drilling of hard-to-machine materials with the drill. For this reason, the studies on the effects of feed rate and cutting speed on the drillability criteria such as cutting force, surface quality and dimension accuracy are still up to date although new drill quality and geometries are improved. In this study, the drillability of ferritic stainless steel with coated and uncoated carbide drill was investigated. The effects of feed rate and cutting speed on the thrust force, surface roughness and deviation of diameter were analyzed experimentally and statistically in drilling of the stainless steel. The experiments were carried out with three different cutting speeds $(15,30$, $45 \mathrm{~m} / \mathrm{min})$ and the feed rates $(0.12,0.16,0.2 \mathrm{~mm} / \mathrm{rev})$ with the carbide drill bit. Analysis of variance was applied to determine the effect levels of the drilling parameters on the machining outputs. According to the experimental results, it was determined that as the feed rate increases, the thrust force and surface roughness increases while the deviation of diameter decreases. Based on the experimental and statistical results, it was found that the coated carbide drill for average surface roughness and deviation of diameter displayed the average of 5.8\% and $8.3 \%$ better performance than uncoated ones, respectively, while the uncoated drill demonstrated the average of $10 \%$ better performance than coated ones for thrust force. https://dx.doi.org/10.30855/gmbd.2019.02.05
\end{abstract}




\section{INTRODUCTION (GIRIS)}

Mühendislik malzemeleri, çeşitli kimyasal ve mekanik özelliklere sahip olup hayatımızın birçok alanında kullanılmaktadır. Hızla gelişen günümüz endüstrisinde, konstrüksiyon/imalat alanının büyük bir kısmını paslanmaz çelik grubu malzemeleri oluşturmaktadır. $\mathrm{Bu}$ grup içerisinde olan ferritik kalite paslanmaz çelikler otomobil şase parçaları, egzos elemanları, sıcak su tankları, mutfak gereçleri ve dekoratif uygulamalar gibi birçok endüstriyel alanda kullanılmakta olup, AISI 409, 430 ve 439 kaliteleri ferritik paslanmaz çeliklere örnek verilebilir [1]. Diğer yandan, düşük isıl genleşme, iyi oksidasyon ve yüksek sıcaklık dayanımı ve östenitik paslanmaz çeliklere göre kolay şekillendirilebilme özelliği, bu grupta yer alan AISI 430 ferritik paslanmaz çeliğin karakteristik özelliklerini oluşturmaktadır [2].

Delik delme işlemi, imalat işlemlerinde sıklıkla kullanılan ve mekanik üretimde büyük öneme sahip olan bir talaş kaldırma yöntemidir [3]. Bu işlemde, aynı anda dönme ve ilerleme hareketi yapan bir kesici takım (matkap) ile takım ve işlenen malzeme cinsi gibi özelliklere bağlı olarak belirlenen kesme hızı ve ilerleme miktarı uygulanarak talaş oluşumu gerçekleştirilir [4]. Delik delme işleminde, kesme hızı ve ilerleme miktarının delik kalitesi, yüzey pürüzlülüğü, kesme kuvveti, moment vb. işlenebilirlik çıktıları üzerindeki rolü son derece önemlidir. $\mathrm{Bu}$ bağlamda, karmaşık bir kesme mekaniğine sahip olan delme işleminin verimliliğini etkileyen bu parametrelerin işlenebilirlik çıktıları üzerindeki etkilerinin araștırılması vazgeçilmez bir süreçtir. Paslanmaz çeliğin işlenebilirliğinin zor olması, sunulan bu çalışmanın önemini daha da artırmaktadır. Delik delme işlemi üzerine birçok çalışma temel parametreler ışığında (kesme hızı, ilerleme miktarı, matkap kalitesi vb.) işleme maliyetini azaltmak, verimliliği arttırmak ve en uygun parametre seviyelerini tespit etmek için gerçekleştirilmektedir. Araştırma konusu ile ilgili yapılan çalışmalardan bazıları aşağıda özetlenmiştir.

Kanagaraju vd., delik delme işleminde kesme parametrelerinin etkilerini tekli kaplama, çoklu kaplama ve kaplamasız karbür takımlarla SAF2507 paslanmaz çelik üzerinde incelemişlerdir. Elde edilen istatistiksel veriler 1şı̆̆ında paslanmaz çeliğin işlenmesinde çok katmanlı kaplamalı takımın diğer takımlara göre daha iyi bir performans gösterdiğini saptamışlardır [5]. Siddique vd., delme işleminde
AISI 321 paslanmaz çeliğinin yüzey pürüzlülüğünü minimize etmek için Taguchi deneysel yöntemi kullanarak en uygun kesme parametrelerini araştırmışlardır. Deneyler sonucunda en uygun parametre seviyeleri $500 \mathrm{dev} / \mathrm{dak}, 0.04 \mathrm{~mm} / \mathrm{s}$ ve delik derinliği $25 \mathrm{~mm}$ olarak tespit edilmiştir [6]. Çaydaş vd., kuru kesme ortamında AISI 304 östenitik paslanmaz çeliğin delinmesinde yüksek hız çeliği (HSS), karbür ve TiN kaplamalı HSS matkapların performanslarını araştırmışlardır. Kesme hızı ve ilerleme miktarının yüzey pürüzlülüğü, takım aşınması ve çapak yüksekliği üzerindeki etkilerini analiz etmişlerdir. TiN kaplamalı HSS matkabın uzun takım ömrü ve delik kalitesi açısından yüksek performans gösterdiğini tespit etmişlerdir [7]. Kıvak vd., TiN, TiAIN ve TiAIN/TiN kaplamalı HSS takımlar kullanarak AISI 316 paslanmaz çeliğin delinebilirliğini araştırmışlar ve işleme verimliliğine etki eden farklı ilerleme miktarı ve kesme hızlarını incelemişlerdir. Araştırmacılar, delik çapı ve dairesellik noktasında en verimli sonucu TiAIN/TiN kaplı takımlardan elde etmişlerdir. Ayrıca, işleme verimliliğini etkileyen delik çapı ve daireselliğin değişiminde, kesme hızının ilerleme miktarına göre daha etkili olduğunu belirtmişlerdir [8]. Sultan vd., kaplamasız karbür matkap ile farklı kesme hızları (18 ve $30 \mathrm{~m} / \mathrm{dak}$ ) ve ilerleme miktarların $(0.03,0.045 \mathrm{ve}$ $0.06 \mathrm{~mm} / \mathrm{rev}$ ) kullanarak AISI 316L çeliğinin delinebilirliğini araştırmışlardır. Kesme hızı arttıkça yüzey pürüzlülüğünün azaldığını ve ilerleme miktarı arttıkça ise yüzey pürüzlülüğünün arttığını tespit etmişlerdir [9].

$\mathrm{Bu}$ çalışmada, AISI 430 ferritik paslanmaz çeliğin kaplamasız ve kaplamalı karbür matkap uçlarıyla delinmesinde meydana gelen ilerleme kuvveti, yüzey pürüzlülüğü ve çaptan sapma üzerinde kesme hızı ve ilerleme miktarının etkileri deneysel ve istatistiksel olarak incelenmiştir. Deneylerde üç farklı kesme hızı ve ilerleme miktarı kullanılmış olup, işleme parametrelerinin delme çıktıları üzerindeki katkı oranlarını belirlemek amacıyla varyans analizi uygulanmıştır.

\section{MATERYAL VE YÖNTEM (MATERIAL AND METHOD)}

Delme işlemlerinde, $100 \times 85 \times 4 \mathrm{~mm}$ ölçülerinde AISI 430 ferritik paslanmaz çelik plakalar kullanılmıştır. Deneysel araştırmalarda kullanılan paslanmaz çeliğin kimyasal bileşimi Tablo 1'de verilmişsir. 
Tablo 1. AISI 430 paslanmaz çeliğin kimyasal bileşimi (Chemical composition of AISI 430 stainless steel)

\begin{tabular}{ccccccc}
\hline $\mathrm{C}$ & $\mathrm{Mn}$ & $\mathrm{P}$ & $\mathrm{S}$ & $\mathrm{Si}$ & $\mathrm{Cr}$ & $\mathrm{Ni}$ \\
\hline 0.12 & 1.0 & 0.045 & 0.03 & 1.0 & 16.0 & 0.75 \\
\hline
\end{tabular}

Deneyler, kuru kesme şartları altında motor gücü 10 HP olan Johnford VMC-550 dik işleme merkezinde yapılmıştır. Kesici takım olarak, KARCAN tarafindan 12M00K1P3DF080079 kodu ile imal edilen $8 \mathrm{~mm}$ çapında, $140^{\circ}$ uç açısı ve $30^{\circ}$ helis açısında kaplamalı ve kaplamasız karbür matkaplar kullanılmıştır. Takım üretici firma ve paslanmaz çeliklerin delinmesi üzerine yapılan araştırmalara dayanılarak kesme parametrelerinin seviyeleri belirlenmiştir. Buna göre, kesme parametreleri olarak üç farklı kesme hızı $(15,30,45$ $\mathrm{m} / \mathrm{dak})$ ve üç farklı ilerleme miktarı $(0.12,0.16,0.2$ $\mathrm{mm} / \mathrm{dev})$ kullanılmıştır. Belirlenen kesme parametrelerine göre her bir deney iki kez tekrar edilmiş, elde edilen ilerleme kuvveti sonuçlarının ortalamaları alınarak değerlendirmeler yapılmıştır.

İlerleme kuvvetinin ölçülmesi ve bilgisayara aktarılmasinda, Kistler 9257A tipi dinamometre, 5070A tipi amplifier ve Dynoware yazılımı kullanılmıştır. Elde edilen deliklerin yüzey pürüzlülük değerleri ise Marsurf M300 pürüzlülük cihazı ile örneklem uzunluğu (Lt) $1.75 \mathrm{~mm}$ ve kesme uzunluğu $(\lambda) 0.25 \mathrm{~mm}$ olarak seçilmiştir. Delik kalitesi için değerlendirmeler, delik boyunca üç farklı yerden yapılan ölçümün aritmetik ortalaması alınarak yapılmıştır. Delik geometrisinin kontrolü için yapılan çaptan sapma ölçümlerinde $0.001 \mathrm{~mm}$ hassasiyetinde ölçüm yapabilen Hexagon Global Performance CMM cihazı kullanılmıştır.

\section{DENEYSEL VE ISTATISTIKSEL ANALIZ (EXPERIMENTAL AND STATISTICAL ANAYSIS)}

AISI 430 paslanmaz çeliğin kaplamalı ve kaplamasız karbür matkaplar ile delinmesinde kesme hızı ve ilerleme miktarına bağlı olarak elde edilen ilerleme kuvveti $(\mathrm{Fz})$, yüzey pürüzlülüğü (Ra) ve çaptan sapma (Dd) değerleri Şekil 1-3'te sırasıyla verilmiştir. Ayrıca, her iki matkap kalitesi için kesme parametrelerinin delme çıktıları üzerindeki etki seviyeleri $\% 95$ güven düzeyinde yapılan varyans analizi ile değerlendirilmiştir. Deneysel ve istatistiksel sonuçlar, diğer paslanmaz çelik kalitelerinin delinmesiyle ilgili çalışmalarla karşılaştırılarak değerlendirilmiştir.

\section{1. İlerleme Kuvveti (Thrust Force)}

Kesme parametrelerine bağlı olarak kaplamasız ve kaplamalı karbür matkaplar için ilerleme kuvveti değişimleri, sırasıyla Şekil 1a ve 1b'de verilmiştir. Şekil 1 incelendiğinde, sabit kesme hızında ilerleme miktarının artması ile $\mathrm{Fz}$ değerlerinde bir artış meydana geldiği açıkça görülmektedir. Bu durum, genel kanı olarak bilinen talaş kesit alanının artmasıyla ilişkilendirilmektedir [10]. Başka bir deyişle, ilerleme miktarının artmasıyla talaş kaldırmak için gerekli gücün artması ilerleme kuvvetinin artmasına neden olmuştur. İlerleme miktarı sabit iken kesme hızının artması durumunda ise ilerleme kuvvetinin bir azalma eğilimi içerisinde olduğu görülmektedir. $\mathrm{Bu}$ durum, birincil deformasyon bölgesinde meydana gelen sıcaklığın artan kesme hızıyla birlikte artması sonucunda iş parçasının yumuşaması ve dolayısıyla malzeme kesme dayanımının azalması ile ilişkilendirilmiştir [11]. Kaplamasız ve kaplamalı karbür matkap için Fz değerleri benzer eğilimde olup, kesme parametrelerindeki oransal değişime göre paralel bir eğilim göstermiştir.
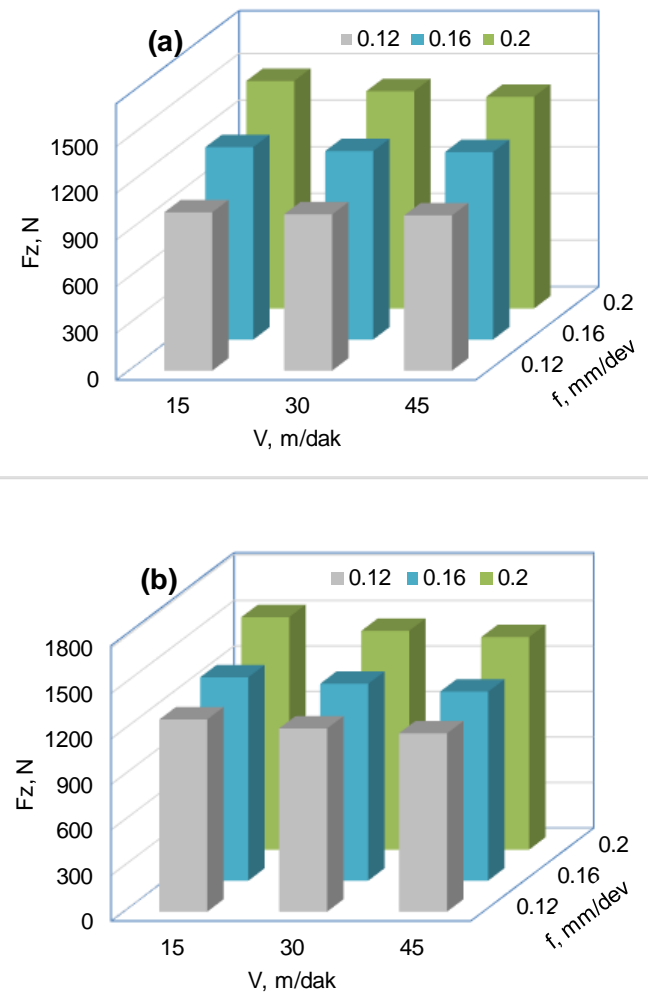
Şekil 1. Fz'nin kesme parametrelerine göre değişimi; a) Kaplamasız, b) Kaplamalı (Variation of Fz according to cutting parameters; a) Uncoated, b) Coated)

Kaplamasız takım için en küçük ilerleme kuvveti $45 \mathrm{~m} /$ dak kesme hızında ve $0.12 \mathrm{~mm} / \mathrm{dev}$ ilerleme miktarında $998 \mathrm{~N}$ olarak ölçülmüştür. En büyük ilerleme kuvveti ise $15 \mathrm{~m} /$ dak kesme hızında ve 0.2 $\mathrm{mm} / \mathrm{dev}$ ilerleme miktarında $1463 \mathrm{~N}$ elde edilmiştir. Kaplamalı karbür matkap için en küçük ilerleme kuvveti aynı kesme şartlarında $1176 \mathrm{~N}$ ölçülürken, en büyük değer 1533 N olarak elde edilmiştir. Şekil 1'den görülebileceği gibi, tüm kesme şartlarında kaplamasız takım ile elde edilen $\mathrm{Fz}$ değerleri kaplamalı takıma göre daha düşüktür. Kesme parametrelerindeki değişim oranlarına göre bu eğilim değişmezken, kaplamasız matkap ile Fz değerleri ortalama \%10 daha düşük elde edilmiştir. $\mathrm{Bu}$ sonuç, kesici takım geometrisiyle ilişkilendirilmiş olup, kaplama malzemesinin matkap kesici kenarından ayrılması ve dolayısıyla takımdaki aşınma nedeniyle meydana gelen talaş oluşumundan kaynaklandığ 1 düşünülmektedir. Şekil 2'den görülebileceği gibi, özellikle matkabın uç kısmında kaplama kalkmasına bağlı olarak kesici kenarlarda talaş yapışması meydana gelmiş ve dolayısıyla takımın maruz kaldığ sürtünme kuvvetleri de artarak ilerleme kuvvetlerinin yükselmesini sağlamıştır.
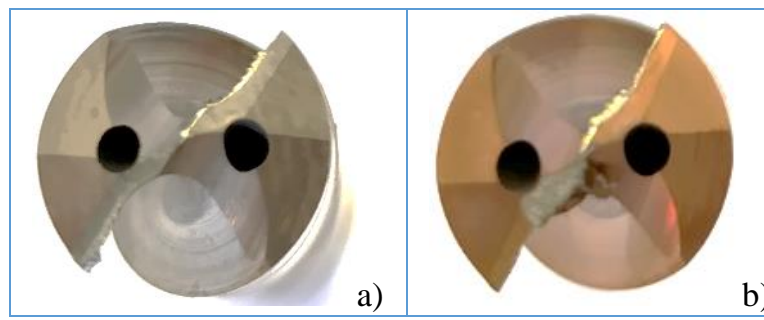

Şekil 2. $V=30 \mathrm{~m} / \mathrm{dak}, \mathrm{f}=0.15 \mathrm{~mm} / \mathrm{dev}$; a) Kaplamasız matkap, b) Kaplamalı matkap ( $V=30 \mathrm{~m} / \mathrm{min}, f=0.15$ $\mathrm{mm} / \mathrm{rev}$; a) Uncoated drill, b) Coated drill)

Kesme parametrelerinin ilerleme kuvveti üzerindeki etki oranlarını belirlemek için yapılan varyans analizi (ANOVA) Tablo 2'de gösterilmiştir. ANOVA tablosunda, her bir parametre için serbestlik derecesi (SD), kareler toplamı (KT), kareler ortalaması (KO), yüzde etki oranı (PCR) ile P değerleri verilmiştir. Kaplamasız karbür matkap için ilerleme kuvveti üzerinde en büyük etkiye sahip parametrenin \%97.52 PCR ile ilerleme miktarı olduğu belirlenmiştir. Diğer yandan, P değerine göre kesme hızının istatistiksel olarak önemli bir parametre olmadığı $(\mathrm{P}>0.05)$, ancak \%1.65'lik etki oranı ile $\mathrm{Fz}$ üzerinde düşük etkiye sahip bir parametre olduğu görülmektedir. Kaplamasız matkapta ise en önemli parametre yine ilerleme miktarı olurken (\%83.59 PCR), kesme hızının önem seviyesi \%15.67 PCR olarak belirlenmiştir.

Tablo 2. Fz için ANOVA sonuçları (ANOVA results for

\begin{tabular}{|c|c|c|c|c|c|c|}
\hline Parametre & SD & KT & KO & F & $\mathrm{P}$ & $\begin{array}{c}\text { PCR } \\
(\%)\end{array}$ \\
\hline \multicolumn{7}{|l|}{$\begin{array}{l}\text { Kaplamasız } \\
\text { matkap }\end{array}$} \\
\hline $\mathrm{f}(\mathrm{mm} / \mathrm{dev})$ & 2 & 240257 & 120128 & 236.81 & 0.000 & 97.52 \\
\hline $\mathrm{V}(\mathrm{m} / \mathrm{dak})$ & 2 & 4070 & 2035 & 4.01 & 0.111 & 1.65 \\
\hline Hata & 4 & 2029 & 507 & & & 0.83 \\
\hline Toplam & 8 & 246356 & & & & 100 \\
\hline \multicolumn{7}{|l|}{$\begin{array}{l}\text { Kaplamalı } \\
\text { matkap }\end{array}$} \\
\hline $\mathrm{f}(\mathrm{mm} / \mathrm{dev})$ & 2 & 91274 & 45636.8 & 226.55 & 0.000 & 83.59 \\
\hline $\mathrm{V}(\mathrm{m} / \mathrm{dak})$ & 2 & 17111 & 8555.4 & 42.47 & 0.002 & 15.67 \\
\hline Hata & 4 & 806 & 201.4 & & & 0.74 \\
\hline Toplam & 8 & 109190 & & & & 100 \\
\hline
\end{tabular}

\subsection{Yüzey Pürüzlülüğü (Surface Roughness)}

Yüzey pürüzlülüğü (Ra) işlenen malzemenin yorulma ömrünü etkilemesi açısından önemli bir yere sahip olup, delik kalitesinin değerlendirilmesi noktasında önemli bir etkendir. Deneysel çalışmalar neticesinde, kaplamasız ve kaplamalı karbür matkaplar için kesme parametrelerine bağlı olarak elde edilen yüzey pürüzlülükleri, sırasıyla Şekil 3a ve 3b'de verilmiştir. Şekil 3'e göre, kesme hızındaki artışla birlikte $\mathrm{Ra}$ değerlerinin azaldığı açıkça görülmektedir. Bu sonuç, kesme hızındaki artışın bir fonksiyonu olarak takım-talaş temas alanında üretilen daha yüksek sıcaklıklar nedeniyle kesici kenarlarda talaş yapışma eğiliminin azalmasıyla açıklanabilir. Diğer yandan, ilerleme miktarının artmasıyla birlikte Ra değerlerinde bir artış eğiliminin meydana geldiği belirlenmiş olup, bu durum beklenen bir sonuçtur. $\mathrm{Bu}$ durumun, ilerleme miktarının artması ile talaş kesit alanının artmasıyla oluşan talaş oluşumundan kaynaklandığı düşünülmektedir. Özellikle düşük kesme hızlarında ve yüksek ilerleme miktarında takım titreşimlerinin artması [12] ilerleme kuvvetiyle birlikte yüzey pürüzlülüğünün artmasına neden olmuştur. Bununla birlikte, ilerleme miktarının artmasıyla talaş tahliyesi kolaylaşmakta, ancak sünek malzemelerin işlenmesinde oluşan kesici kenarda talaş yapışmaları düzensiz kesmeye neden olarak pürüzlülüğün artmasına katk1 sağladığı düşünülmektedir.

Kaplamasız karbür matkap için en küçük yüzey pürüzlülüğü $45 \mathrm{~m} /$ dak kesme hızında ve 0.12 $\mathrm{mm} / \mathrm{dev}$ ilerleme miktarında $1.458 \mu \mathrm{m}$ olarak ölçülmüştür. En büyük yüzey pürüzlülüğü $15 \mathrm{~m} / \mathrm{dak}$ kesme hızında ve $0.2 \mathrm{~mm} / \mathrm{dev}$ ilerlemede $1.904 \mu \mathrm{m}$ 
elde edilmiştir. Kaplamalı takım için en küçük pürüzlülük değeri aynı kesme şartlarında $1.379 \mu \mathrm{m}$ ölçülürken, en büyük değer $1.781 \mu \mathrm{m}$ olarak elde edilmiştir.

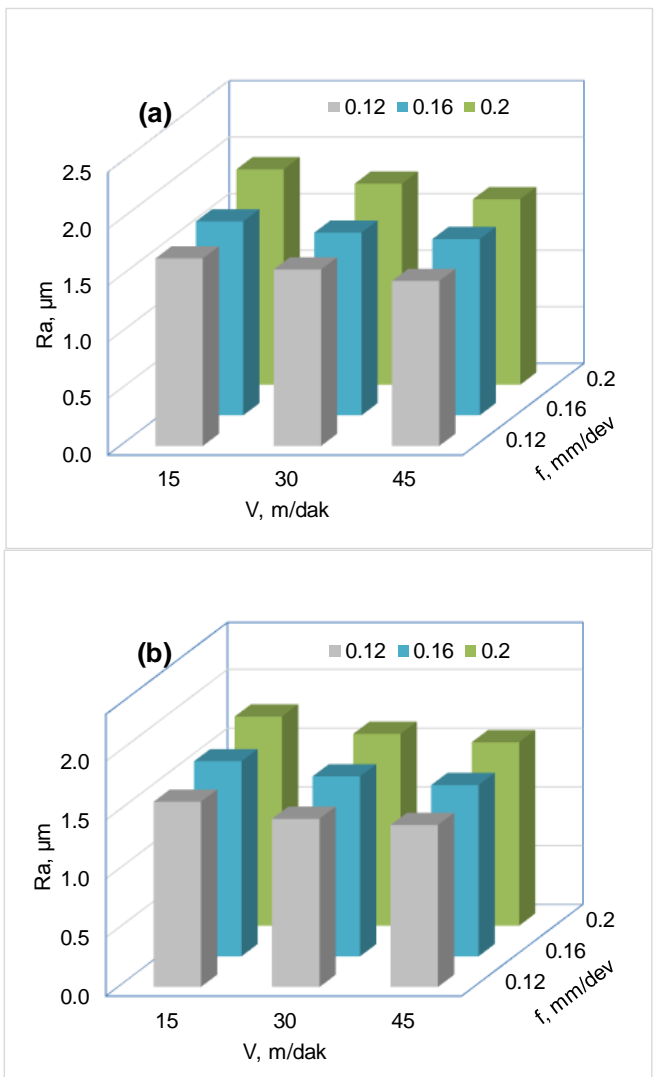

Şekil 3. Ra'nın kesme parametrelerine göre değişimi, a) Kaplamasız, b) Kaplamalı (Variation of Ra according to cutting parameters; a) Uncoated, b) Coated)

Tüm kesme şartlarında kaplamalı matkap ile elde edilen $\mathrm{Ra}$ değerleri kaplamasız takıma göre daha düşüktür. $\mathrm{Bu}$ sonuç, literatürde bahsedildiği gibi, kaplamalı matkabın yüksek aşınma direnci [13] ve düşük sürtünme katsayı [14] ile ilişkilendirilmiştir. Kesme parametrelerindeki değişim oranlarına göre bu eğilim benzer şekilde olup, kaplamalı karbür matkap ile $\mathrm{Ra}$ değerleri ortalama \%5.8 daha düşük elde edilmiştir. Ra için uygulanan varyans analizine göre, kaplamasız matkap için yüzey pürüzlülüğü üzerinde en büyük etkiye sahip parametre $\% 51.74$ PCR ile ilerleme miktarıdır. Kesme hızının ise \%45.89 PCR ile diğer önemli parametre olduğu görülmektedir (Tablo 3). Kaplamalı matkapta ise işleme parametrelerinin $\mathrm{Ra}$ üzerindeki önem sıralaması değişmiş olup, kesme hızı ve ilerleme miktarının sirasıyla $\% 46.30$ ve $\% 53.51$ PCR'lik bir etkiye sahip olduğu belirlenmiştir. Bu sonuç, yüzey pürüzlülüğünün özellikle sünek malzemelerin delme işleminde oluşan sıcaklığa da duyarlı olduğunu göstermektedir.

Tablo 3. Ra için ANOVA sonuçları (ANOVA results for $R a)$

\begin{tabular}{lcccccc}
$\begin{array}{l}\text { Parametre } \\
\text { Paplamasız }\end{array}$ & SD & KT & KO & F & P & $\begin{array}{c}\text { PCR } \\
(\%)\end{array}$ \\
\hline $\begin{array}{l}\text { Katkap } \\
\text { m (mm/dev) }\end{array}$ & 2 & 0.072291 & 0.036145 & 43.7 & 0.002 & 51.74 \\
V (m/dak) & 2 & 0.064117 & 0.032058 & 38.76 & 0.002 & 45.89 \\
Hata & 4 & 0.003309 & 0.000827 & & & 2.37 \\
Toplam & 8 & 0.139716 & & & & 100 \\
\hline $\begin{array}{l}\text { Kaplamalı } \\
\text { matkap }\end{array}$ & & & & & & \\
\hline f (mm/dev) & 2 & 0.057838 & 0.028919 & 490.61 & 0.000 & 46.30 \\
V (m/dak) & 2 & 0.066854 & 0.033427 & 567.1 & 0.000 & 53.51 \\
Hata & 4 & 0.000236 & 0.000059 & & & 0.19 \\
Toplam & 8 & 0.124928 & & & & 100 \\
\hline
\end{tabular}

\section{3. Çaptan Sapma (Deviation of Diameter)}

Matkap ile açılan bir deliğin imalat resminde istenen ölçü ve geometrik toleranslarda elde edilmesi oldukça zordur. Takım geometrisi, kesme ortamı, malzeme cinsi ve yapısı, kesme parametreleri vb. birçok işlenebilirlik kriterine ilave olarak kesme işleminin kapalı bir ortamda yapılması delme işlemi çıktılarının kontrolünü zorlaştırmaktadır. Delme işlemi sonucunda oluşan delik kalitesi kontrol kriterlerinden birisi de çaptan sapma (Dd) değeridir. $\mathrm{Bu}$ bağlamda, kaplamasız ve kaplamalı karbür matkaplar ile paslanmaz çeliğin delinmesinde elde edilen çaptan sapma değerlerinin kesme parametrelerine göre değişimleri, sırasıyla Şekil 4a ve 4 b'de verilmiştir.

Şekil 4'e göre, her iki matkap kalitesi için ilerleme hızındaki artışla birlikte çaptan sapmanın azaldığ 1 görülmektedir. Bu durumun, ilerlemedeki artışa bağlı olarak talaş tahliyesinin hızlanması ve takım-iş parçası arasındaki temas süresinin azalması ve böylece sürtünmeye bağlı oluşan sıcaklık artışının azalmasından kaynaklandığı düşünülmektedir. Diğer yandan, kesme hızındaki artış oranına bağlı olarak Dd değerlerinin düzenli bir eğilim sergilemediği görülmektedir. Kesme hızının $15 \mathrm{~m}$ /dak'dan 30 m/dak'ya artmasıyla çaptan sapmalar azalırken, kesme hızının $45 \mathrm{~m}$ /dak'ya çıkarılmasıyla Dd değerleri tekrar artış eğilimine girmiştir. Bu sonuç, kısmen kesme hızındaki artışın bir fonksiyonu olarak sıcaklığın artması ve paslanmaz çeliğin düşük 1sıl iletkenliğine [15] bağlı oluşan talaş oluşumuna 
atfedilmiştir. Ayrıca, kesme hızındaki artışla birlikte tezgah ve matkap titreşiminin muhtemelen artması ve buna bağlı olarak matkabın delik ekseninden sapmasıyla delik çaplarının arttığı düşünülmektedir. İlerleme ve kesme hızındaki değişimlere bağlı oluşan çaptan sapmalar, sürtünme katsayısının daha düşük olması [16] nedeniyle kaplamalı matkaplar için daha küçük değerlerde elde edilmiştir.
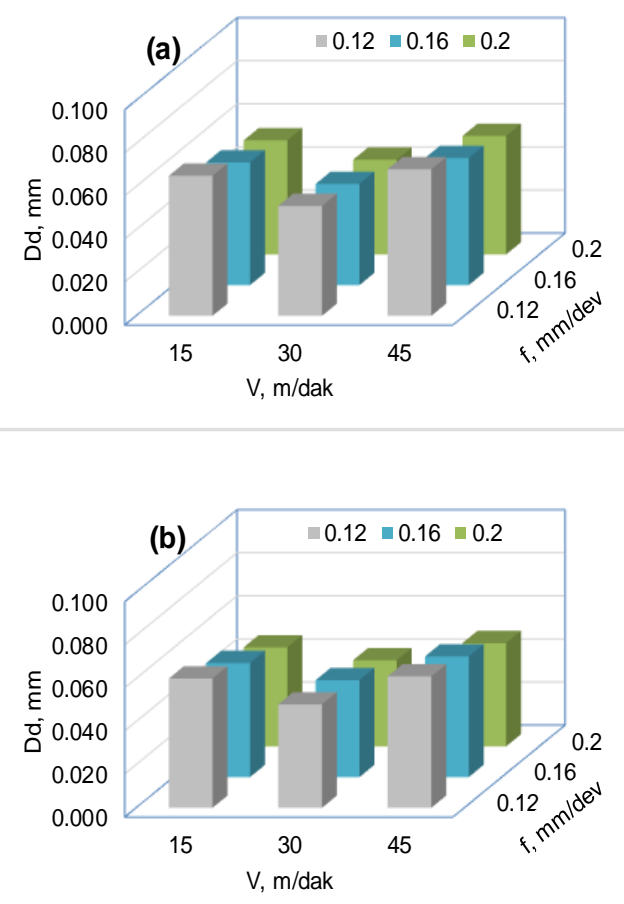

Şekil 4. Dd'nin kesme parametrelerine göre değişimi, a) Kaplamasız, b) Kaplamalı (Variation of Dd according to cutting parameters; a) Uncoated, b) Coated)

Kaplamasız karbür matkap için en küçük Dd değeri $30 \mathrm{~m} /$ dak kesme hızında ve $0.2 \mathrm{~mm} / \mathrm{dev}$ ilerleme miktarında $0.044 \mathrm{~mm}$ olarak ölçülmüştür. En büyük çaptan sapma $45 \mathrm{~m} /$ dak kesme hızında ve $0.12 \mathrm{~mm} / \mathrm{dev}$ ilerlemede $0.068 \mathrm{~mm}$ elde edilmiştir. Kaplamalı matkap için en küçük çaptan sapma değeri aynı kesme şartlarında $0.040 \mathrm{~mm}$ ölçülürken, en büyük değer $0.061 \mathrm{~mm}$ olarak belirlenmiştir. Tüm kesme şartlarında kaplamalı matkap ile elde edilen Dd değerleri kaplamasız takıma göre daha düşüktür. $\mathrm{Bu}$ durum, kesici takım kaplama malzemesine atfedilebilir. Kaplamasız matkaplara göre kaplamalı matkaplarla yapılan işlemlerde talaşın daha az sürtünme kuvveti ve daha kolay tahliyesi matkabın delik ekseninden daha az sapmasına yol açmıştır. Dolayısıyla, kaplamalı matkaplarla yapılan işlemlerde daha düşük çaptan sapma değerleri elde edilmiştir. Kesme parametrelerine göre bu eğilim benzer şekilde olup, kaplamalı karbür matkap ile Dd değerleri ortalama \%8.3 daha düşük elde edilmiştir. Varyans analizi sonuçlarına göre, kaplamasız matkap için çaptan sapma üzerinde en büyük etkiye sahip parametre \%61.79 PCR ile kesme hızıdır. İlerleme miktarının ise \%35.77 PCR'lik bir etkiye sahip olduğu görülmektedir (Tablo 4). Kaplamalı matkap için çaptan sapma üzerinde işleme parametrelerinin önem sıralaması değişmiş olup, ilerleme miktarı ve kesme hızının sirasıyla \%50.25 ve \%47.07 PCR'lik bir etkiye sahip oldukları belirlenmiştir.

Tablo 4. Dd için ANOVA sonuçları (ANOVA results for $D d)$

\begin{tabular}{lcccccc}
\hline Parametre & SD & KT & KO & F & P & $\begin{array}{c}\text { PCR } \\
(\%)\end{array}$ \\
\hline $\begin{array}{l}\text { Kaplamasiz } \\
\text { matkap }\end{array}$ & & & & & & \\
\hline $\mathrm{f}(\mathrm{mm} / \mathrm{dev})$ & 2 & 0.000176 & 0.000088 & 29.92 & 0.004 & 35.77 \\
$\mathrm{~V}(\mathrm{~m} / \mathrm{dak})$ & 2 & 0.000304 & 0.000152 & 51.66 & 0.001 & 61.79 \\
Hata & 4 & 0.000012 & 0.000003 & & & 2.44 \\
Toplam & 8 & 0.000492 & & & & 100 \\
\hline $\begin{array}{l}\text { Kaplamal1 } \\
\text { matkap }\end{array}$ & & & & & & \\
\hline $\mathrm{f}(\mathrm{mm} / \mathrm{dev})$ & 2 & 0.000206 & 0.000103 & 37.00 & 0.003 & 50.25 \\
V (m/dak) & 2 & 0.000193 & 0.000096 & 34.72 & 0.003 & 47.07 \\
Hata & 4 & 0.000011 & 0.000003 & & & 2.68 \\
Toplam & 8 & 0.00041 & & & & 100 \\
\hline
\end{tabular}

\section{SONUÇLAR}

AISI 430 ferritik paslanmaz çelik malzemenin delinmesinde, kaplamasız ve kaplamalı karbür matkapların performansları ve delik kalitesinin araştırıldığı bu çalışmadan elde edilen sonuçlar aşağıda özetlenmiştir.

- İlerleme miktarının artmasıyla ilerleme kuvveti (Fz) artarken, kesme hizının artmasiyla $\mathrm{Fz}$ değerlerinin bir miktar azaldığı belirlenmiştir. Kaplamalı matkaplarda, Fz kuvvetleri ortalama \%10 daha büyük elde edilmiştir.

- Kaplamasız karbür matkap ile en küçük yüzey pürüzlülüğü $45 \mathrm{~m} /$ dak kesme hızı ve $0.12 \mathrm{~mm} / \mathrm{dev}$ ilerleme miktarında $1.458 \mu \mathrm{m}$ olarak ölçülürken, kaplamalı takım ile en küçük Ra değeri aynı kesme şartlarında $1.379 \mu \mathrm{m}$ olarak elde edilmiştir.

- ANOVA sonuçlarına göre, kaplamasız matkapla elde edilen Ra için kesme hızı \%45.89, kaplamalı matkapta ise \%53.51'lik bir öneme sahiptir. Bu sonuç, sünek malzemelerin delinmesinde yüzey pürüzlülüğü açısından kesme hızının ilerleme hızı kadar önemli olduğunu göstermektedir.

- İlerleme miktarındaki oransal artışa paralel olarak çaptan sapma (Dd) azalırken, kesme hızının artmasıyla Dd değerlerindeki değişim aynı paralellikte olmamıştır. Bununla birlikte, kaplamalı 
karbür matkap ile Dd değerleri ortalama \%8.3 daha düşük elde edilmiştir.

- Deneysel ve istatistiksel sonuçlara göre, yüzey pürüzlülüğü ve çaptan sapma için kaplamalı karbür matkap, ilerleme kuvveti için kaplamasız matkabın daha iyi performans gösterdiği tespit edilmiştir.

\section{TEŞEKKÜR (ACKNOWLEDGEMENT)}

Yazarlar, bu çalışmaya verilen maddi destekten dolayı Karabük Üniversitesi BAP Koordinatörlüğü'ne (KBÜBAP-17-YL-248) teşekkür eder.

\section{KAYNAKLAR (REFERENCES)}

[1] A. Aran ve M.A. Temel, Paslanmaz Çelik Yassı Mamuller Üretimi, Kullanımı, Standartları. İstanbul: Acar Matbaacılık A.Ş., 2004.

[2] M.E. Korkmaz, "Ferritik paslanmaz çeliğin malzeme yapısal denklem parametrelerinin belirlenmesi ve doğrulanması", Düzce Üniversitesi Bilim ve Teknoloji Dergisi, 7, 628-639, 2019.

[3] Ş. Bayraktar, Y. Siyambaş ve Y. Turgut, "Delik delme prosesi: bir araştırma", Sakarya Üniversitesi Fen Bilimleri Enstitüsü Dergisi, 21(2), 120-130, 2016.

[4] J.T. Black and R.A. Kohser, Degarmo's Materials and Processes in Manufacturing. New Jersey: Prentice-Hall Inc., 2013.

[5] T. Kanagaraju, M. Kumar, R. Mahesh, R. Manikandan and S. Shanmugapandiyan, "Influence of drilling parameters in super duplex stainless steel", International Journal of Advanced Research Trends in Engineering and Technology, 3, 445-451, 2016.

[6] A.N. Siddique, Z.A. Khan, P. Goel, M. Kumar, G. Agarwal and N.Z. Khan, "Optimization of deep drilling process parameters of AISI 321 steel using Taguchi method", Procedia Materials Science, 6, 1217-1225, 2014.

[7] U. Çaydaş, A. Hasçalık, Ö. Buytoz and A. Meyveci, "Performance evaluation of different twist drills in dry drilling of AISI 304 austenitic stainless steel", Materials and Manufacturing Processes, 26, 951-960, 2011.

[8] T. Kıvak, A. Çiçek, İ. Uygur ve N.A. Özbek, "AISI 316 östenitik paslanmaz çeliğin delinmesinde tek katlı ve çok katlı kaplamaların delik kalitesi üzerindeki etkileri”, 3. Ulusal Talaşlı Imalat Sempozyumu, Ankara, Türkiye, 2012, 28-34.

[9] A.Z. Sultan, S. Sharif and D. Kurniawan, "Effect of machining parameters on tool wear and hole quality of AISI $316 \mathrm{~L}$ stainless steel in conventional drilling", Procedia Manufacturing, 2, 202-207, 2015. [10] G. Küçüktürk, "Modeling and analyzing the effect of experimentally determined torque and thrust force on cutting tool according to drilling parameters", Proc Inst Mech Eng, Part B: Journal of Engineering Manufacture, 227(1), 84-95, 2012.

[11] M.E. Korkmaz, T. Meral ve M. Günay, "AISI 420 Martenzitik paslanmaz çeliğin delinebilirliğinin sonlu elemanlar yöntemiyle analizi”, Gazi Mühendislik Bilimleri Dergisi, 4(3), 223-229, 2018.

[12] S. Sharif and E.A. Rahim, "Performance of coated and uncoated-carbide tools when drilling titanium alloy Ti6Al4V", Journal of Materials Processing Technology, 185, 72-76, 2007.

[13] İ. Tekaüt ve H. Demir, "AISI H13 VE AISI D2 çeliklerinin delinmesi esnasında kesme bölgesinde oluşan sıcaklığa kesici takım kaplamasının ve işleme parametrelerinin etkisi”, Gazi Üniversitesi Mühendislik Mimarlık Fakültesi Dergisi, 30(2), 289296, 2015.

[14] A.Z. Sultan, S. Sharif, F.M. Nor and D. Kurniawan, "Minimum quantity of lubricant drilling of stainless steel using refined palm olein: Effect of coating tool on surface roughness and tool wear", Procedia Manufacturing, 30, 427-434, 2019.

[15] M. Günay, “AISI 316L çeliğinin işlenmesinde takım radyüsü ve kesme parametrelerinin taguchi yöntemiyle optimizasyonu", Gazi Üniversitesi Mühendislik-Mimarlık Fakültesi Dergisi, 28(3), 437 444, 2013.

[16] S. Yağmur, A. Acır ve U. Şeker, “AISI 1050 Çeliğinin delinmesinde kesme parametrelerinin ve kaplama uygulamasının dairesellikten sapma (ovalite) üzerindeki etkilerinin araştırılması", Politeknik Dergisi, 16(3), 105-109, 2013. 


\section{Tolga MERAL}

Tolga MERAL, 1992 y1lında Artvin'de doğmuştur. 2015 yılında Karabük Üniversitesi Makine Mühendisliği Bölümü’nden mezun olmuştur. 2018 yılında KBÜ Fen Bilimleri Enstitüsü Makine Mühendisliği Anabilim Dalı'nda yüksek lisans eğitimini tamamlamış ve şuan doktora programına devam etmektedir. 2019 yılında, Bursa Uludağ Üniversitesi Teknik Bilimler Meslek Yüksekokulu'nda Öğr. Gör. olarak çalışmaya başlamıştır. Sonlu elemanlar yöntemi, talaşlı imalat, deney tasarımı ve CAD/CAM/CAE konularında çalışmaktadır.

\section{Mustafa GÜNAY}

Mustafa GÜNAY, 1978 yılında Bursa'da doğmuştur. 2000 yılında GÜ Teknik Eğitim Fakültesi Makine Eğitimi Bölümü'nden mezun olmuştur. GÜ Fen Bilimleri Enstitüsü Makine Eğitimi Bölümü'nde yüksek lisans ve doktora eğitimlerini, sirasıly 2003 ve 2009 yıllarında tamamlamıştır. 2001 yılında Gazi Üniversitesi'nde araştırma görevlisi olarak başlamış olduğu akademik kariyerini, 2009-2013 yılları arasında KBÜ Mühendislik Fakültesi Makine Mühendisliği Bölümü'nde Dr. Öğr. Üyesi olarak devam ettirmiştir. 2013 yılında Doçent ünvanı alan GÜNAY, 2019 yılından beri KBÜ Mühendislik Fakültesi Makine Mühendisliği Bölümü'nde Profesör olarak akademik kariyerini sürdürmektedir. Geleneksel ve geleneksel olmayan imalat yöntemleri, takım tezgahları, kompozit malzemeler, kesici takım teknolojileri, toz metalurjisi, CAD/CAM/CAE alanlarında deney tasarımı ve optimizasyona dayalı çalışmalar yapmaktadır. 